\title{
Planned organizational change to transform care to workers exposed to biological material
}

\author{
A mudança organizacional planejada para transformação do atendimento ao trabalhador \\ acidentado com material biológico
}

\section{Cambio organizativo planificado para transformar la atención del trabajador accidentado con material biológico}

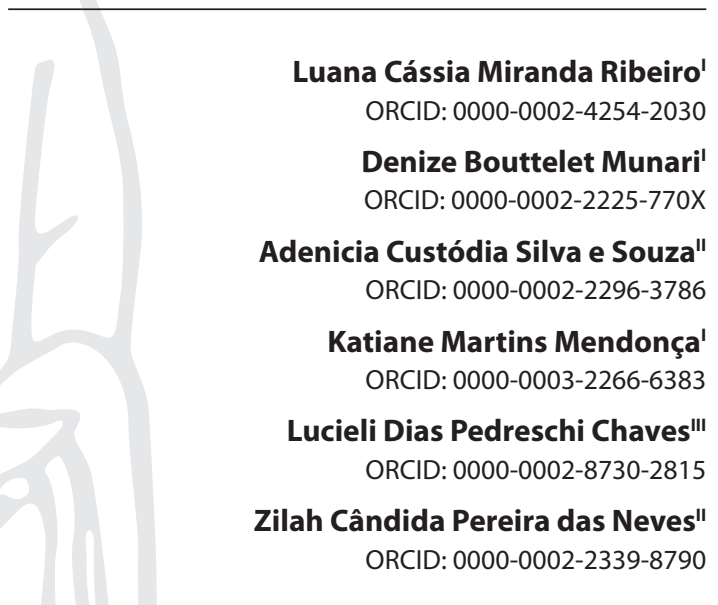

'Universidade Federal de Goiás. Goiânia, Goiás, Brazil. "Pontifícia Universidade Católica de Goiás. Goiânia, Goiás, Brazil. I'Universidade de São Paulo. Ribeirão Preto-São Paulo, Brazil.

How to cite this article: Ribeiro LCM, Munari DB, Souza ACS, Mendonça KM Chaves LDP, Neves ZCP. Planned organizational change to transform care to workers exposed to biological material. Rev Bras Enferm. 2020;73(5):e20190314 doi: http://dx.doi.org/10.1590/0034-7167-2019-0314

Corresponding author: Luana Cássia Miranda Ribeiro E-mail: luaufg@yahoo.com.br

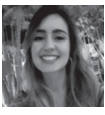

EDITOR IN CHIEF: Antonio José de Almeida Filho ASSOCIATE EDITOR: Priscilla Valladares Broca

Submission: 07-05-2019

Approval: 10-28-2019

\section{ABSTRACT}

Objectives: to describe the evaluation of the service offered in cases of occupational accidents involving exposure to biological material, from the perspective of the exposed workers, before and after an intervention to obtain planned organizational change. Methods: descriptive study with a qualitative approach, carried out with workers exposed to biological material who received care at a reference service that was submitted to an intervention based on planned organizational change. Data were collected by using the critical incident technique and analyzed from the perspective of content analysis. Results: twenty exposed workers participated in the study and were split into two groups in the pre- and postintervention phase. Categories regarding improvement in the guidance they received reduction in the time they waited once they got to the facility, organization of the process, documentation qualification, and professionalism in carrying out the assistance emerged from the workers' accounts. Conclusions: the present study allowed the exposed workers to visualize the changes that happened in the care management in case of accidents involving biological material. Additionally, there was the recognition of the adopted methodological path, which allowed the active participation of the people involved.

Descriptors: Nursing; Exposure to Biological Agents; Intervention Studies; Evaluation; Organizational Innovation.

\section{RESUMO}

Objetivos: descrever a avaliação do atendimento aos casos de acidentes ocupacionais com material biológico, na perspectiva do trabalhador acidentado, antes e após uma intervenção para mudança organizacional planejada. Métodos: pesquisa descritiva, de abordagem qualitativa, realizada com trabalhadores acidentados com material biológico atendidos em um serviço de referência que passou por uma intervenção baseada na mudança organizacional planejada. Dados coletados por meio da técnica do incidente crítico e analisados à luz da análise de conteúdo. Resultados: participaram do estudo vinte trabalhadores acidentados divididos em dois grupos, nas fases pré e pós-intervenção. Das falas, emergiram categorias referentes a melhoria das orientações, redução do tempo, organização do processo, qualificação da documentação e profissionalismo na realização do atendimento. Conclusões: a investigação permitiu aos acidentados visualização das mudanças ocorridas na gestão do atendimento em caso de acidente com material biológico, além disso, houve o reconhecimento acerca do percurso metodológico adotado que permitiu a participação ativa dos envolvidos.

Descritores: Enfermagem; Exposição a Agentes Biológicos; Estudos de Intervenção; Avaliação; Inovação Organizacional.

\section{RESUMEN}

Objetivos: describir la evaluación de la atención de casos de accidentes laborales con material biológico desde la perspectiva del accidentado, antes y después de una intervención de cambio organizativo planificado. Métodos: investigación descriptiva, de abordaje cualitativo, realizada con trabajadores accidentados con material biológico atendidos en servicio de referencia donde ocurrió una intervención de cambio organizativo planificado. Datos recolectados mediante técnica del incidente crítico, analizados según análisis de contenido. Resultados: participaron del estudio veinte trabajadores accidentados, divididos en dos grupos en fases preintervención y postintervención. De sus testimonios emergieron categorías referentes a mejora de sugerencias, reducción del tiempo, organización del proceso, calificación de la documentación y profesionalismo en la atención. Conclusiones: el estudio permitió que los accidentados observaran los cambios realizados en la gestión de la atención en casos de accidentes con material biológico. Además, recibió reconocimiento la trayectoria metodológica adoptada, que permitió la participación activa de los involucrados.

Descriptores: Enfermería; Exposición a Agentes Biológicos; Estudios de Intervención; Evaluación; Innovación Organizacional. 


\section{INTRODUCTION}

Occupational accidents involving biological material are a worrying reality, because they can lead to serious consequences to the exposed workers, such as the possibility of seroconversion $^{(1-2)}$ and psychoemotional and social changes ${ }^{(3-4)}$. Knowledge reported in studies on the subject offer resources to develop a gold standard to provide effective care to these workers.

This type of care requires a minimum level of organization of the work process, which includes infrastructure to provide assistance, material resources (medications, vaccines, and test kits), and human resources that have technical and scientific knowledge to make decisions ${ }^{(5)}$.

A highly qualified interdisciplinary team can make a difference in the care offered to exposed workers, especially by correctly evaluating the source person (if known), quickly requesting the necessary serological tests, and indicating chemoprophylaxis when it is suitable, in addition to providing advice, reporting, and following the treatment outcome ${ }^{(5)}$.

Despite the strategic importance of the management of accidents involving biological material as a way to properly provide care to workers that go through occupational accidents, the literature seems to neglect this important discussion. Most of the studies mentioned in a review on the subject limited themselves to characterizing the accidents, the workers who went through them ${ }^{(1,6-8)}$, the factors associated with the occurrence of the episodes $^{(9-10)}$, and the consequences that came up $\mathrm{p}^{(1-4,11)}$.

Studies have recognized the importance of providing proper care to workers exposed to biological material ${ }^{(2,12)}$, but investigations addressing the management of the care process considering the involved people, the circumstances, the structure of the process, and the way to carry it out aiming to obtain a qualified assistance were not found, which proved to be a gap to be bridged by the present study.

Given the available evidence, an intervention oriented toward proposing changes in the management of the service provided to workers exposed to biological material was designed. This process involved changes in organizational aspects, in the training of the healthcare professionals who work at the facilities where the service to this public is provided, and in the evaluation of the quality of the service and its management. The present study was proposed as one of the ways to assess the changes resulting from this intervention.

\section{OBJECTIVES}

To describe the evaluation of the service provided to cases of occupational accidents involving biological material from the perspective of the exposed workers, before and after an intervention oriented toward achieving a planned organizational change (POC).

\section{METHODS}

\section{Ethical aspects}

The proposal was approved by the research ethics committee of the Hospital de Doenças Tropicais as per protocol no. 046/2009, with an addendum attached in 2013 as per protocol no. 390,639/2013 regarding the ethical and legal aspects advocated for research involving human beings, in accordance with Resolution 466/2012 of the Brazilian National Health Council.

\section{Study design}

A descriptive study, with a qualitative approach ${ }^{(13)}$, was carried out from 2014 to 2015 in the capital of a state in the Central-West Region of Brazil. Given the type of study, its execution was guided by the principles of the Consolidated Criteria for Reporting Qualitative Research (COREQ): a 32-item checklist for interviews and focus groups.

The investigation was performed before and after the design of an intervention based on the POC model ${ }^{(14-17)}$ aiming to improve the service offered to people exposed to biological material. This model has the strong commitment of the participants of the study to the change process as one of its principles ${ }^{(16)}$. The POC characteristics that caused it to be chosen as the model to guide the intervention are the value given to the experience of professionals and the attempt by them to establish a commitment to the implementation of the changes ${ }^{(16-17)}$.

The intervention was carried out at a reference service that offers care to workers exposed to biological material, following the steps stipulated in the POC model, over 15 months. During the unfreezing process, a focus group was held with the key professionals at the service to achieve nucleation and situation diagnosis. The action phase included two focus groups carried out to draft a flow chart with the steps of the service to be offered to people exposed to biological material and come up with suggestions to improve this service. Based on the results obtained in this phase, 21 group meetings occurred to train all the professionals that worked at the unit, from receptionists to prescribers. The last phase, related to refreezing, was the opportunity to monitor and evaluate the professionals regarding the performed training and was carried out immediately after the group meetings as well as five months after their completion.

It is important to emphasize that the present paper reports the perspective of the users on all the work carried out, before and after the intervention.

\section{Participants}

The participants of the present study were 20 workers who went through occupational accidents involving the exposure to biological material that were assisted at the reference service previously mentioned. Taking into account the qualitative nature of the study, the participants were the people assisted before and after the intervention oriented toward improving the service to this specific type of public. The goal was to use the opinion of the users of the service as a reference to the suggestions to improve the offered care as a way of evaluating the impact of the implemented changes.

\section{Selection criteria}

Inclusion criteria were workers who had an accident involving exposure to biological material, before and after the implementation of the mentioned intervention in the reference service. Because the study focused on the evaluation of the care delivered to people that were exposed to biological material, the participants of the pre- and post-intervention phases were 
different. They were located by consulting the registration form at the Occupational Health Reference Center (CEREST, as per its acronym in Portuguese), and those who answered the phone call up to the third attempt were invited to be included in the sample. It is noteworthy that no worker contacted to participate declined the invitation.

The participants were identified by checking the investigation form for occupational accidents involving biological material, made available by the CEREST, and contacted by phone. During the phone calls, they were invited to participate in the study and their authorization was requested. The search for participants was carried out from the oldest to the newest case, taking the reporting date as the reference and considering one year as the limit period between the occurrence of the accident and the moment data were collected. This criterion was applied to try to gather people who had a preserved recollection of the accident.

\section{Data collection}

Data were obtained in two moments: the first quarter of 2014 (before the intervention) and the third quarter of 2015 (five months after the end of the intervention and the implementation of the changes in the service management). After verbal acceptance, a place and time were agreed for the researchers to conduct a semistructured interview with the workers, which lasted 40 minutes on the average and was applied according to the critical incident technique $(\mathrm{CIT})^{(18)}$. All the interviewees received information about the objectives and methodology of the study and signed a free and informed consent form.

The data collection instrument was a semi-structured script that had two parts. The first was related to the occupational health and safety at work risk profile. The second, based on the CIT, was guiding questions addressing the situation, the behavior, and the consequences of the moment of the delivery of care and the evaluation of the experience the workers had, covering the conducts of the healthcare professionals that assisted them. The researcher that conducted the interview ensured the identification of the three elements that characterize critical incidents: situation, behavior, and consequence ${ }^{(18)}$.

The choice of the CIT in the present study was based on the potential critical incidents have to contextualize certain situations, a characteristic especially useful in the intended evaluation to both study and identify the effects of the implemented intervention. Because the focus was qualitative analysis of the accounts according to the CIT, the collection was ended when data theoretical saturation was reached ${ }^{(19)}$, which considers that "an ideal qualitative sample is the one that reflects, in quantity and intensity, the multiple dimensions of a certain phenomenon and seeks the quality of the actions and interactions over the whole process". Consequently, this principle considers the researcher's analysis before the data as well as the evaluation that including new participants will not contribute to improving the reflection.

\section{Data analysis}

Considering the qualitative nature of the generated data, descriptive analysis followed, as well as content analysis in the thematic modality, which consists of an initial skim reading of the material to extract the central ideas and the posterior identification of meaning cores and data thematic categories ${ }^{(20)}$. The ATLAS.ti software was used to systematize the analysis process and manage the text data.

Data were labeled with a code consisting of the initials of the profession name followed by the order of execution of the interview. In the pre-intervention phase, there were: NUR1 (nurse, interview 1); SUR2 and SUR7 (surgical technologists, interviews 2 and 7); and NURT3, NURT4, NURT5, NURT6, NURT8, NURT9, and NURT10 (nursing technicians, interviews 3, 4, 5, $6,8,9$, and 10). The post-intervention phase included NURT1, NURT2, NURT3, NURT5, NURT6, NURT8, NURT9, and NURT10 (nursing technicians, interviews 1, 2, 3, 5, 6, 8, 9, and 10); GSA4 (general services assistant, interview 4); and LT7 (laboratory technician, interview 7).

\section{RESULTS}

Twenty workers who went through an accident involving exposure to biological material were the study sample. They were allocated into two groups, with ten examined in the preintervention phase and ten in the post-intervention phase. Regarding the occupational health and safety at work risk profile of the workers that participated in the first phase of the study, nine were women, among whom five were married and six had children. Regarding their profession, seven were nursing technicians, one was a nurse, and two were surgical technologists, with a time since graduation and a time of professional practice shorter than ten years. Seven reported that they had already received guidance on biosafety. Eight participants declared that they had already gone through another accident over their career and only five mentioned to have knowledge about the service flow chart. All of them reported the accident on the same day it happened.

In the post-intervention phase, all the interviewees were women, of whom four were single, four were married, and six did not have children. Regarding their profession, eight were nursing technicians, one was a nursing undergraduate student, and one was a general services assistant. Six participants had been graduated for less than ten years and eight had a time of professional practice also shorter than ten years. The ten professionals in this group informed that they had already received information on biosafety, seven declared that they had not gone through another accident over their career, and seven knew the service flow chart before the accident.

Thorough reading and analysis of the material derived from the interviews allowed to organize the data into categories that describe, from the perspective of the workers who went through an accident, the evaluation of the service they received after the episode involving exposure to biological material. This reading occurred in two moments, the pre- and post-intervention phases, to design changes in the management of this process. The accounts that supported this analysis are shown in Chart 1.

In addition to the specific changes identified by the users and related to the problems detected in the pre- and post-intervention phases, illustrated in Chart 1, other aspects were mentioned as changes resulting from the intervention. 
Chart 1 - Pre- and post-intervention evaluation of the service delivered to workers who went through an accident involving exposure to biological material by the workers themselves, Goiânia, Goiás, Brazil, 2015

\begin{tabular}{|c|c|c|}
\hline Category & Pre-intervention evaluation & Post-intervention evaluation \\
\hline $\begin{array}{l}\text { Guidance over } \\
\text { the delivery of } \\
\text { the service }\end{array}$ & $\begin{array}{l}\text { I collected the blood sample and they said "You can bring it here" (...) } \\
\text { The follow-up is being carried out here and they did not tell me to go } \\
\text { back to the CEREST or anything. (NUR1) } \\
\text { The nurse gave me no instructions (...) I did not receive any other } \\
\text { instruction there except to go to the reference center. (SUR2) } \\
\text { I did not call the Center of Reference in Diagnosis and Treatment yet, } \\
\text { that I did not do. He did not tell me after how long I should call (...) } \\
\text { but he did not mention follow-up. (NURT3) } \\
\text { I did not know that it was necessary to schedule the appointment } \\
\text { and nobody told me who was going to do it. (NURT6) }\end{array}$ & $\begin{array}{l}\text { I had explanations after the care procedures, Ilearned with that. The } \\
\text { nurse herself explained many things to me that I did not know until } \\
\text { that moment. She talked about the care procedures and the step- } \\
\text { by-step process that I should execute. Now I can guide other people } \\
\text { when it is necessary, they offered me guidance on everything, Ilearned } \\
\text { about it if I need it again. (NURT2) } \\
\text { First, the receptionist called a nurse to give me instructions, carry out } \\
\text { my registration, how it all happened (...) I considered that the nurse } \\
\text { offered me correct guidance. (NURT5) } \\
\text { The people who attended me were trained and had knowledge to } \\
\text { offer the instructions. (LT7) }\end{array}$ \\
\hline $\begin{array}{l}\text { Time and } \\
\text { organization for } \\
\text { the execution of } \\
\text { the service }\end{array}$ & $\begin{array}{l}\text { The service took too long to happen, when we got there, we waited } \\
\text { for over an hour to be attended. (SUR2) } \\
\text { I told the receptionist it was an accident involving exposure to } \\
\text { biological material, when we got there we immediately told what } \\
\text { had happened, then she said "Go to that station and talk to the } \\
\text { nurse" (...) I was referred to the medical care, which took too long } \\
\text { too, about } 40 \text { minutes, nearly an hour. (SUR2) } \\
\text { The result of this experience is my not going back there because of } \\
\text { the delay. (SUR2) }\end{array}$ & $\begin{array}{l}\text { After I was referred to the doctor on duty it was all very fast, I stayed } \\
\text { there for less than an hour to solve everything. (NURT1) } \\
\text { There they do all they have to do nicely, offer a good service, give a lot } \\
\text { of priority to biological accidents, that is why it is good, when you tell } \\
\text { them what it is it is automatic, they immediately send you in. The nurse } \\
\text { is very quick in interviewing and sends you to the lab right away, it } \\
\text { seems it is all a sequence, I felt it was organized in that regard. (NURT8) } \\
\text { I said it was an occupational accident and, because there was a shift } \\
\text { change going on, the service was a bit of a mess and they asked me to } \\
\text { wait (...) I arrived at the reception at } 7 \text { pm, they attended me at 8:30 pm } \\
\text { approximately, I think it was because of the shift change. (NURT5) }\end{array}$ \\
\hline $\begin{array}{l}\text { Care-related } \\
\text { documentation }\end{array}$ & $\begin{array}{l}\text { He told me I had to go to the reference center but he did not give me } \\
\text { any paper, he just said that I had to look for. (NURT6) } \\
\text { They told me I had to have a follow-up with an infectious disease } \\
\text { specialist, I do not know for how long, I cannot remember. They said } \\
\text { where it is, but I do not remember either. (NURT8) }\end{array}$ & $\begin{array}{l}\text { They evaluated me, both the nurse and the doctor, and they gave me a } \\
\text { paper saying that I should follow it and have other tests. (NURT2) } \\
\text { The nurse that closed my case gave me a paper that is in my bag, } \\
\text { she gave me the instruction to go to the reference center and get an } \\
\text { appointment with the infectious disease specialist. (NURT3) } \\
\text { After the lab, I got a paper saying that I had to go through a follow-up. } \\
\text { They gave me this paper and all the instructions, as well as the paper } \\
\text { for me to collect the test result. (NURT8) }\end{array}$ \\
\hline $\begin{array}{l}\text { Professionalism in } \\
\text { the execution of } \\
\text { the service }\end{array}$ & $\begin{array}{l}\text { Ifound the experience negative, very bad, the lowest possible grade, } \\
\text { because of the delay, lack of professionalism, and impoliteness of the } \\
\text { professionals in general, all of them. (SUR2) } \\
\text { When I went picking up the test result, they were very rude to me, you } \\
\text { know those people who have been working at the same place for a } \\
\text { long time, those senior public servants that should be kept away from } \\
\text { patients, so, that is how they treated me at the lab. (SUR7) } \\
\text { The doctor's copy wasn't taken, the form was left behind, I think they } \\
\text { forgot to bring it to me. (NURT6) }\end{array}$ & $\begin{array}{l}\text { They treated me very well and gave me all the instructions. (NURT2) } \\
\text { The service at the unit was very good. (NURT10) } \\
\text { The service they provided me with was good. (NURT6) } \\
\text { They attended me well (...) a good service, they calm you down, talk to } \\
\text { you. (NURT8) } \\
\text { The professionals were very receptive, I considered that they provided a } \\
\text { good service, it was all right. (NURT9) }\end{array}$ \\
\hline
\end{tabular}

Chart 2 - Changes in the offered service after the intervention emphasized by the workers who went through accidents involving exposure to biological material, Goiânia, Goiás, Brazil, 2015

\begin{tabular}{|c|c|}
\hline Category & Representative account excerpts \\
\hline $\begin{array}{l}\text { Changes in the team's } \\
\text { attitude: commitment and } \\
\text { responsibility }\end{array}$ & $\begin{array}{l}\text { The accident happened around } 6 \mathrm{pm} \text {, I arrived during the night shift. The place was closed to the public and it was receiving } \\
\text { accident and emergency cases, the Mobile First-aid Service, and the fire department only. Although the facility was not open } \\
\text { to the general public, the service offered by the professional was normal and fast. (NURT1) } \\
\text { I got to the reception and said it was an accident involving exposure to biological material, they immediately referred me to } \\
\text { a nurse. She said she needed the patients' blood, she made a phone call to get it, led me to her office, and kept on providing } \\
\text { care, everything that was necessary. (NURT2) } \\
\text { The receptionist sent me in straight away, Ijust said my name and informed my ID number. (GSA4) } \\
\text { I got there and the receptionist sent me in immediately, there was also an old lady who was waiting there and the receptionist } \\
\text { talked to her, "Just a minute, madam, it is a case involving exposure to biological material and it has priority". (LT7) } \\
\text { When inside, the nurse collected even more data, sent them to the laboratory, accompanied me all the time, even during the } \\
\text { quick tests, referred me to the medical appointment so the doctor could examine me. (NURT9) }\end{array}$ \\
\hline $\begin{array}{l}\text { Integration of the laboratory } \\
\text { into the offered service }\end{array}$ & $\begin{array}{l}\text { The professional who attended me referred me to the laboratory so I had a blood sample collected, it was all very quick } \\
\text { there, everything normal, no delay. (NURT1) } \\
\text { There was a documentation confusion at the laboratory, there was this very nice old lady who said "My child, I am going to } \\
\text { help you", I do not even remember her name, she immediately got a form and filled it in with my data because I knew my ID } \\
\text { number and my social security number by heart and all I had was my hospital badge. (NURT5) }\end{array}$ \\
\hline $\begin{array}{l}\text { Execution of the service } \\
\text { according to the flow chart }\end{array}$ & $\begin{array}{l}\text { When there, I talked to the nurse, went to the laboratory, had a blood sample collected, talked to the doctor and then to } \\
\text { the nurse, who gave me a paper. They referred me to the reference center. (GSA4) } \\
\text { After I was examined by the doctor, they (doctor and nurse) talked and told me that I was discharged. (NURT5) }\end{array}$ \\
\hline $\begin{array}{l}\text { Direct delivery of the source's } \\
\text { quick test result to the person } \\
\text { responsible for the service }\end{array}$ & $\begin{array}{l}\text { I got the result of the quick test right then and there with the nurse. (NURT1) } \\
\text { The laboratory sent the result and the nurse called me to inform it to me. (NURT5) } \\
\text { We were at the doctor's office, the result already came. (NURT9) }\end{array}$ \\
\hline
\end{tabular}


Chart 2 lists changes associated with the intervention, which were mostly related to four aspects. The first shows the impact of training the whole team so these people would commit to the service. The second reveals the consequences of the change in the way the team that worked at the laboratory interacted in the service process. The third stresses the adequacy of the service to the flow chart of the service delivered to workers who go through accidents involving biological material, and the fourth emphasizes the importance of handing over the test results directly to the professional responsible for the service. The descriptions pertaining to these aspects are gathered in Chart 2 .

\section{DISCUSSION}

Studies in the health area, especially in nursing, indicate that there is a predominance of women in this profession worldwide ${ }^{(7-8,21)}$. This variable was shown as statistically significant for the occurrence of accidents involving exposure to biological material ${ }^{(8)}$. In nursing, the prevalence of this type of exposure is high ${ }^{(7,21-22)}$.

The first category listed in Chart 1 referred to the changes in the "guidance over the delivery of the service", which were positively evaluated by the participants, given that the received instructions regarding the accident were explained, especially about what to do in these cases and the measures to be taken. A study stressed the importance of workers being aware of their rights and responsibilities when faced with pre- and postexposure measures that aim to ensure their safety and health ${ }^{(8)}$.

The first care is considered an emergency and must be carried out in a proper place, with privacy and no judgments. Analysis of the episode must identify risk attitudes, such as work overload, the availability, and use of personal protective equipment, and the handling of sharps with safety apparatus ${ }^{(5)}$.

At the moment the service is delivered, accurate instructions must be provided, for instance the service flow chart, possible serological results, and the clinical and laboratory follow-up. When this step is neglected, the whole process is compromised, including the closure of the case ${ }^{(12)}$. An example of this situation can be found in the findings of the present study about the pre-intervention phase, in which the workers who went through an accident showed insecurity regarding how to act, resulting even in treatment withdrawal. Conversely, the results obtained in the post-intervention phase indicated how important user embracement is. An investigation performed in Thailand emphasized inadequate post-exposure conducts and the impacts experienced by the workers who went through occupational accidents, stressing the importance of effective post-exposure training ${ }^{(11)}$.

Despite the need for and the relevance of the service and follow-up to these workers exposed to biological material, Brazilian and international studies showed that there are few units that offer a proper structure to carry out these activities. They also indicated that continuing education programs neglect the subject ${ }^{(7-8,23-24)}$.

Although official documents in the Brazilian and global spheres make updates available to guide professionals who work providing care and managing care and follow-up to people who were exposed to biological material, studies emphasized the importance of designing monitoring and evaluation guidelines and protocols for workers who went through accidents ${ }^{(22,25)}$.

"Time and organization for the execution of the service" was another category in which data pointed to the fact that reorganization and quickness in the service delivery process after the intervention made the offered service more efficient, even when it had to meet a detailed proposed flow chart, from the arrival at the reception up to the final appointment.

This quickness may be the differential for workers who go through accidents to choose whether they will seek care and follow the instructions or omit the accident episode ${ }^{(10,26)}$. The two-hour period to evaluate the accident and begin chemoprophylaxis, when it is indicated, must be considered the gold standard in this type of service ${ }^{(5)}$.

The third category illustrated that the "care-related documentation" may be an obstacle when it is not complete and/or organized. This aspect may have consequences for both workers and professionals who attend them, as revealed in the results related to the pre-intervention phase (Chart 1 ). This factor draws attention because it implicates legal questions concerning the involved people, in addition to violating occupational health and safety principles, especially when the accident causes exposure to biological material, which is a complication of mandatory reporting provided for in the legislation ${ }^{(5)}$.

A study with the objective of identifying the rate of underreporting of accidents involving biological material by nursing teams and the reasons mentioned for this phenomenon pointed to bureaucracy and the delay in filling out the documents as justifications for non-reporting ${ }^{(9,21,27-28)}$. This perception reveals the lack of knowledge of the real meaning of reporting an accident involving exposure to biological material, which goes beyond statistics and directly impacts workers' health and labor issues ${ }^{(5)}$.

It is noteworthy that the interviewed workers recognized the importance of the documents and evaluated the instructions provided by the professionals responsible for the service as important to the continuity of the treatment, which is known to favor the fulfillment of the existing rules and the workers' safety.

"Professionalism in the execution of the service" was a category that emphasized the relevance of a proper conduct by the professionals responsible for the service before people who go through this type of accident. The discrepancy in the accounts given by the workers in the pre- and post-intervention phases stressed the impact of the intervention on the improvement of the behavior of the professionals who provided the service. The findings showed that the results of the intervention were positive and transformative, especially with a more adequate and proactive attitude by the professionals who carry out the service, which originated satisfaction in the participants regarding the way they were received and the guidance on the necessary conducts to monitor the consequences of the accident, as well as more clarity in the service flow chart.

These pieces of evidence reinforce the need to train the team that will provide this initial care to the workers who go through occupational accidents, a moment that often is decisive for the continuity of the treatment or not. Theoretical and scientific knowledge combined with humanization is indispensable, 
especially when considering the feelings that emerge immediately after an exposure episode, such as concern, lack of control, fear, despair, insecurity, shock, stigmatization, anxiety, and low level of confidence, among others ${ }^{(3,7,29)}$. Accidents are not limited to biological and economic consequences: they also stir up psychoemotional aspects, which influence quality of life directly and cause stress in workers, their family, and work colleagues.

The results mentioned in Chart 2 showed specific aspects in which the intervention was more successful regarding the achievement of changes in the management of the service offered to the workers who went through an accident involving exposure to biological material. The change of attitude of the team, the integration of the involved sectors, the use of the flow chart, and the delivery of test results were points stressed by the workers who resorted to the service after the implementation of the intervention.

Regarding the "changes in the team's attitude: commitment and responsibility", all the members of the team, including those who worked at the reception, began adopting conducts in accordance with what was established in the protocol designed with the team during the intervention. A study demonstrated that training and education related to exposure to biological material must be adapted according to the characteristics of the professionals who carry out the service and follow-up ${ }^{(30)}$.

The findings in this category strengthened the idea that the team's understanding of the risks present in accidents involving exposure to biological material and the urgency and rigor with which the service must be offered to the exposed workers are fundamental in change processes and service improvement, hence the relevance of collectively designing service protocols and flow charts, both adapted to the institution's reality.

The data gathered in the category "Integration of the laboratory into the offered service" reinforced this idea, because they emphasized the satisfaction the participants experienced after the intervention, with the integration of the laboratory into the service flow. This was pointed as a hindering aspect before the changes in the service process (Chart 1).

The data used as a basis for the third category, "Execution of the service according to the flow chart", and the fourth, "Direct delivery of the source's quick test result to the person responsible for the service", emphasized the incorporation of the flow chart into the practice and the alteration of the delivery of the quick test result. These two items showed improvement in the organization of management and care, which were recognized by the workers who had been through an accident.

Taking into account the results obtained in all the categories listed in the present study that showed changes regarding the processes of the service delivered to people occupationally exposed to biological material, the use of POC ${ }^{(16-17)}$ could be noticed, because it favors this kind of conduct and commitment by the involved people. It is important to stress that these changes were possible because of the type of planning and methodology proposed in the intervention, which is pointed in studies as having the property to promote changes in different contexts ${ }^{(16-17,31)}$.

\section{Study limitations}

Carrying out the study in just one reference service reality may be considered a possible limitation when the possibility of generalizing the findings is envisaged. However, application of rigor and diligence in the execution of the study regarding the observance of the steps and the time for collection of post-intervention data to verify possible changes after the intervention, as well as the comprehensive discussion, are aspects that illustrate the innovative nature of the present study concerning the subject.

\section{Contributions to the field}

The results of the present study provide answers to the gaps identified in the literature, especially for bringing the perspective of the service users that raise reflections on the practice. The findings also indicate ways to adjust the conduct of multidisciplinary teams involved in the process of delivering care to workers who go through accidents involving exposure to biological material, pointing to new directions for the care to this public.

\section{FINAL CONSIDERATIONS}

Evaluating the cases of occupational accidents involving exposure to biological material from the perspective of exposed workers allowed to perform a diagnosis of how the service was carried out and show the impact of the changes resulting from the intervention based on POC in this context.

In assessing the pre- and post-intervention service, the participants recognized that there was improvement in the received instructions, organization, and quickness to perform the appointment, in addition to stressing the professionalism over the execution of the service and the use of documents that made the care process easier. The participants also pointed specific changes proposed during the intervention phase that addressed the team's commitment to the service, the integration of the laboratory team into the process, the adjustment of the service so it would meet the flow chart previously designed by the professionals of the sentinel service, and the direct delivery of the source's quick test result to the person responsible for the service.

In considering the difficulty to promote changes in the health context, characterized by complexity and rooted concepts and pre-established ideas that hinder transformation processes, the present study represents a relevant progress in the training of the management of the service delivered to people exposed to biological material during occupational accidents, especially in an area that is so important and with such a reduced number of intervention studies as occupational health. Another relevant aspect was the adopted methodological path, guided by POC and participatory management, a trend that has been applied worldwide to integrate the involved people into the change process.

\section{FUNDING}

Goiás Research Foundation. 


\section{REFERENCES}

1. Lee JH, Cho J, Kim YJ, Im SH, Jang ES, Kim JW, et al. Occupational blood exposures in health care workers: incidence, characteristics, and transmission of bloodborne pathogens in South Korea. BMC Public Health. 2017;17(1):827. doi: 10.1186/s12889-017-4844-0

2. Hasak JM, Novak CB, Patterson JMM, Mackinnon SE. Prevalence of Needlestick Injuries, Attitude Changes, and Prevention Practices Over 12 Years in an Urban Academic Hospital Surgery Department. Ann Surg. 2018;267(2):291-6. doi: 10.1097/SLA.0000000000002178

3. Januário GC, Carvalho PCF, Moraes JT, Santos MA, Gir E, Toffano SEM. Symptoms of posttraumatic stress disorder after exposure to biological material. Esc Anna Nery 2017;21(4):e20170129. doi: 10.1590/2177-9465-EAN-2017-0129

4. Cooke CE, Stephens JM. Clinical, economic, and humanistic burden of needlestick injuries in healthcare workers. Med Devices (Auckl). 2017;10:225-35. doi: 10.2147/MDER.S140846

5. Ministério da Saúde (BR). Secretaria de Vigilância em Saúde. Protocolo Clínico e Diretrizes Terapêuticas para Profilaxia Pós-Exposição (PEP) de Risco à Infecção pelo HIV, IST e Hepatites Virais. Brasília (Brasil): Ministério da Saúde; 2017.

6. Auta A, Adewuyi EO, Tor-Anyiin A, Aziz D, Ogbole E, Ogbonna BO, et al. Health-care workers' occupational exposures to body fluids in 21 countries in Africa: systematic review and meta-analysis. Bull World Health Organ. 2017;95(12):831-41F. doi: 10.2471/BLT.17.195735

7. Carvalho DC, Rocha JC, Gimenes MCA, Santos EC, Valim MD. Work incidents with biological material in the nursing team of a hospital in MidWestern Brazil. Esc Anna Nery. 2018;22(1):e20170140. doi: 10.1590/2177-9465-EAN-2017-0140

8. Barros DX, Tipple AFV, Lima LKOL, Souza ACS, Neves ZCP, Salgado TA. Analysis of 10 years of accidents with biological material among the nursing staff. Rev. Eletr. Enf. 2016;18:e1157. doi: 10.5216/ree.v18.35493

9. Cui Z, Zhu J, Zhang X, Wang B, Li X. Sharp injuries: a cross-sectional study among health care workers in a provincial teaching hospital in China. Environ Health Prev Med. 2018;23(1):2. doi: 10.1186/s12199-017-0691-y

10. Goel V, Kumar D, Lingaiah R, Singh S. Occurrence of needlestick and injuries among health-care workers of a tertiary care teaching hospital in North India. J Lab Physicians. 2017;9(1):20-5. doi: 10.4103/0974-2727.187917

11. Kasatpibal N, Whitney JD, Katechanok S, Ngamsakulrat S, Malairungsakul B, Sirikulsathean P, et al. Practices and impacts post-exposure to blood and body fluid in operating room nurses: A cross-sectional study. Int J Nurs Stud. 2016;57:39-47. doi: 10.1016/j.jpurstu.2016.01.010

12. Escudero DV, Furtado GH, Medeiros EA. Healthcare worker adherence to follow-up after occupational exposure to blood and body fluids at a teaching hospital in Brazil. Ann Occup Hyg. 2015;59(5):566-71. doi: 10.1093/annhyg/meu117

13. Bogdan R, Biklen S. Investigação qualitativa em educação. Porto: Porto Editora, 2010.

14. Lewin K. Action research and minority problems. J Soc Issues. 1946;2(4):34-46. doi: 10.1111/j.1540-4560.1946.tb02295.x

15. Shirey MR. Lewin's theory of planned change as a strategic resource. J Nurs Adm. 2013;43(2):69-72. doi: 10.1097/NNA.0b013e31827f20a9

16. Evans JN, Ball LS, Whicher CP. Implementation of medical orders for life-sustaining treatment. Clin J Oncol Nurs. 2016;20(1):74-8. doi: 10.1188/16.CJON.74-78

17. Park A, Chang H, Lee KJ. Action research on development and application of internet of things services in hospital. Healthc Inform Res. 2017;23(1):25-34. doi: 10.4258/hir.2017.23.1.25

18. Flanagan J. A técnica do incidente crítico. Arq. Bras. de Psicologia Aplicada. 1973;21(2):99-141.

19. Minayo MCP. Sampling and saturation in qualitative research: consensuses and controversies. Revista Pesquisa Qualitativa. 2017;5(7):1-12.

20. Bardin L. Análise de conteúdo. Portugal: Edições 70; 2011.

21. Kassa G, Selenic D, Lahuerta M, Gaolathe T, Liu Y, Letang G, et al. Occupational exposure to bloodborne pathogens among health care workers in Botswana: reporting and utilization of postexposure prophylaxis. Am J Infect Control. 2016;44(8):879-85. doi: 10.1016/j.ajic.2016.01.027

22. Al-Khatib IA, El Ansari W, Areqat TA, Darkhawaia RA, Mansour SH, Tucktuck MA, et al. Occupational safety precautions among nurses at four hospitals, Nablus district, Palestine. Int J Occup Environ Med. 2015;6(4):243-6. doi: 10.15171/ijoem.2015.581

23. Jager $P$, Zungu $M$, Dyers RE. Economic evaluation of safety-engineered devices and training in reducing needlestick injuries among healthcare workers in South Africa. S Afr Med J. 2018;108(6):477-83. doi: 10.7196/SAMJ.2018.v108i6.12913

24. Triassi M, Pennino F. Infectious risk for healthcare workers: evaluation and prevention. Ann Ig. 2018;30(4 Supple 1):48-51. doi: 10.7416/ ai.2018.2234

25. Samargandy SA, Bukhari LM, Samargandy SA, Bahlas RS, Aldigs EK, Alawi MA, et al. Epidemiology and clinical consequences of occupational exposure to blood and other body fluids in a university hospital in Saudi Arabia. Saudi Med J. 2016;37(7):783-90. doi: 10.15537/ smj.2016.7.14261

26. Mussi M, Marasea DCC. The perspective of occupational accidents underreporting with dentists. Rev. bras. odontol. 2016;73(2):112-7. doi: 10.18363/rbo.v73n2.p.112

27. Barbosa ASAA, Diogo GA, Salotti SRA, Silva SMUR. Underreporting of occupational accidents with biological materials involving nursing professionals in a public hospital. Rev Bras Med Trab. 2017;15(1):12-7. 
28. Ferreira MD, Pimenta FR, Gir E, Canini SRMS. Biological accidents underreporting by nursing professionals of a university hospital. Cienc Enferm. 2015;XXI(2):21-9.

29. Rodrigues PS, Matos MCB, Marques DM, Machado MB, Magro MCS, Hermann PRS. Accident with biological material: perception of the nursing professionals of emergency service. Rev Pre Infec e Saúde. 2017;3(1):23-8. doi: 10.26694/repis.v3i2.6448

30. Bush C, Schmid K, Rupp ME, Watanabe-Galloway S, Wolford B, Sandkovsky U. Bloodborne pathogen exposures: difference in reporting rates and individual predictors among health care personnel. Am J Infect Control. 2017;45(4):372-6. doi: 10.1016/j.ajic.2016.11.028

31. Ramos CFV, Araruna RC, Lima CMF, Santana CLA, Tanaka LH. Práticas educativas: pesquisa-ação com enfermeiros da Estratégia de Saúde da Família. Rev Bras Enferm. 2018;71(3):1144-51. doi: 10.1590/0034-7167-2017-0284 